doi: $10.15407 /$ ukrbotj73.04.385

Yu.Ya. TYKHONENKO, V.P. HELUTA, I.O. DUDKA

M.G. Kholodny Institute of Botany, National Academy of Sciences of Ukraine

2, Tereshchenkivska Str., Kyiv, 01004, Ukraine

yu.ya.tykhonenko@gmail.com

\title{
NEW RECORDS OF THE INVASIVE FUNGUS MELAMPSORIDIUM HIRATSUKANUM (PUCCINIALES) IN UKRAINE
}

Tykhonenko Yu.Ya., Heluta V.P., Dudka I.O. New records of the invasive fungus Melampsoridium hiratsukanum (Pucciniales) in Ukraine. Ukr. Bot. J., 2016, 73(4): 385-389.

M.G. Kholodny Institute of Botany, National Academy of Sciences of Ukraine

2, Tereshchenkivska Str., Kyiv, 01004, Ukraine

Abstract. In Vyzhnytsia National Nature Park (Chernivtsi Region, Ukraine), an invasive rust fungus Melampsoridium hiratsukanum was recorded on the new for Ukraine host plants, Alnus glutinosa and Alnus $\times$ pubescens, the natural hybrid of A. incana and A. glutinosa. In Europe M. hiratsukanum is currently known from Austria, Czech Republic, Denmark, Estonia, Finland, Hungary, Germany, Italy, Latvia, Lithuania, Norway, Poland, Romania, Russia, Slovakia, Sweden, Switzerland, Turkey, UK, and Ukraine. At present, the distribution of M. hiratsukanum in Ukraine is confined to the Ukrainian Carpathians; however, it could not be excluded that in future it may spread into the lowland part of the country. A list of all localities in which M. hiratsukanum was recorded in Ukraine is presented. The article is illustrated by micrographs obtained by scanning electron microscopy.

Key words: rust fungi, Alnus glutinosa, Alnus $\times$ pubescens, Carpathians, distribution, morphology

\section{Introduction}

For the first time in Europe, an East Asian rust fungus Melampsoridium hiratsukanum S. Ito ex Hirats. f. was noted in 1996 on Alnus incana (L.) Moench in Estonia (Põldmaa, 1997) and Latvia (Hantula, Scholler, 2013); the following year it was found in Finland (Kurkela et al., 1998, 1999; Hantula et al., 2009; Lilja et al. 2011) and Lithuania (Markovskaja, 2013). Subsequently, as a typical invasive species, it has been rapidly spreading to the west and south. In Europe, besides the already mentioned countries, this fungus was up to now recorded in Austria (Rigler-Hager et al., 2003; Kruse, 2013), Czech Republic (Dietrich, 2005; Müller, 2003), Denmark (Hantula, Scholler, 2013), Germany (Scholler, 1999; Scholler et al., 2010; Kruse, 2013), Hungary (Szabo, 2002), Italy (Moricca, Maresi, 2010), Norway (Gjaerum et al., 2004), Poland (Wołczańska, 1999; Piątek et al., 2001; Mułenko et al., 2006), Romania (Negrean, Anastasiu, 2006), Russia (Hantula, Scholler, 2013; Bulgakov et al., 2014), Slovakia (Kokeš, 2004), Sweden (Gjaerum et al., 2004; Hantula, Scholler, 2013), Switzerland (Meier et al., 2003), Turkey (Sert, Sumbul, 2005), UK (Stringer, 2010; Hantula et al. 2012), and Ukraine (Tykhonenko, 2011; Tykhonenko, Heluta, 2014).

The aims of this publication are to inform about records of $M$. hiratsukanum on the new for Ukraine host plants and collate the information on currently known localities of this fungus in Ukraine.

(c) Yu.Ya. TYKHONENKO, V.P. HELUTA, I.O. DUDKA, 2016

\section{Matherials and methods}

Specimens collected in the field were labelled and dried for further treatment. Urediniospores mounted in water and/or lactic acid were investigated by light microscopy under Primo Star microscope and AxioVision 4.7 software, used as well for measurements of microstructures. For scanning electron microscopy samples were coated with an ultrathin coating of gold by ion beam sputtering unit JFC-1100. Images were obtained by scanning electron microscope JEOL JSM6060 LA.

The specimens are deposited in Mycological Herbarium of M.G. Kholodny Institute of Botany, National Academy of Sciences of Ukraine $(K W)$.

\section{Results and discussion}

According to literature data, M. hiratsukanum was observed in Scotland and Ireland as early as the beginning of the $20^{\text {th }}$ century (Wilson, Henderson, 1966), but from later publications (Roll-Hansen, RollHansen, 1981; Henderson, Bennell, 1979) it was shown that the parasite of birch, M. betulinum (Pers.) Kleb., can also infect alder and that all previously known European records of the rust on Alnus Mill. belong to this species. Studies using molecular phylogenetic methods (Hantula et al., 2009) confirmed that M. hiratsukanum appeared in Europe in the mid-1990s, while in the UK (Scotland) on Alnus glutinosa (L.) Gaertn. occurs endemic rust indistinguishable from $M$. betulinum. It should be noted 
that several records of $M$. betulinum on A. glutinosa were also reported for Belgium (Vanderweyen, 2010). The rust of alder is also known from New Zealand, but as it was shown by molecular phylogenetic analysis, the pathogen there is $M$. betulinum, not M. hiratsukanum (McKenzie et al., 2013).

Most records of $M$. hiratsukanum in Europe are reported on $A$. incana. On $A$. glutinosa this fungus occurs much less frequently; moreover, in many cases it was recorded on seedlings (Piątek et al., 2001), in forest nursery (Szabo, 2002), or in close proximity to infected plants of $A$. incana (Müller, 2003 Markovskaja, 2013). In Germany it was collected on Duschekia alnobetula (Ehrh.) Pouzar (syn. A. viridis (Chaix) DC.) (Kruse, 2014), in Turkey - on A. orientalis Decne. (Sert, Sumbul, 2005). There are two records of M. hiratsukanum on Betula pubescens Ehrh. in the UK, confirmed by molecular methods (Lane et al., 2013). In Ukraine, M. hiratsukanum was first reported from Gorgany Nature Reserve on A. incana in the end of August 2010 (Tykhonenko, 2011). In subsequent years on the same host plant more samples were collected in other parts of the Ukrainian Carpathians (see a list at the end of the article). During mycological surveys in Vyzhnytsia National Nature Park (Chernivtsi Region) on 23-24 August 2015, the development of this fungus was noted on A. glutinosa and Alnus $\times$ pubescens Tausch (a natural hybrid of $A$. incana and $A$. glutinosa). On both of these species, the rust was observed in the immediate proximity to heavily infected plants of $A$. incana. The morphological features of the fungus on $A$. glutinosa and Alnus $\times$ pubescens are consistent with the diagnosis of $M$. hiratsukanum and distinct from the close species, $M$. betulinum. In particular, the entire surface of its urediniospores is covered with more or less uniform spines, while in $M$. betulinum the spines gradually decrease in size from the base to the upper part of spore so that its top is a free of spines smooth area (Figure, $b$, $d, f)$. Furthermore, ostiolar cells of uredinium are much longer (up to $40 \mu \mathrm{m}$ on $A$. glutinosa and up to $46 \mu \mathrm{m}$ on Alnus $\times$ pubescens) than those of $M$. betulinum (up to $20 \mu \mathrm{m}$ ) (Figure, $a, c, e$ ). Urediniospores size in our specimens of M. hiratsukanum $(18.2-25.1 \times 8.8-10,6$ $\mu \mathrm{m}$ on A. glutinosa and $19.0-26.4 \times 9.2-13.1 \mu \mathrm{m}$ on Alnus $\times$ pubescens) are slightly smaller than those of M. betulinum on Betula pubescens Ehrh. (20.6-29.0 $\times 9.0-12.0 \mu \mathrm{m})$ in a specimen collected in the same region of the Ukrainian Carpathians. According to our observations ostiolar cells obviously play an important role in the release of urediniospores: in response to humidity changes, they bend and unbend to close and open the mouth of uredinium.

At present, the distribution of $M$. hiratsukanum in Ukraine is confined to the Ukrainian Carpathians; however, it could not be excluded that in future the fungus may spread into the lowland part of the country. This rust causing premature defoliation, which certainly affects the physiological state of plants, is of significant environmental importance in riparian habitats.

A list of currently known localities of Melampsoridium hiratsukanum S. Ito ex Hirats. f. in Ukraine.

On Alnus incana (L.) Moench.

\section{Chernivtsi Region}

Putyla District: Cheremoskyi National Nature Park, Perkalabske environmental parcel, forest on the bank of Sarata river, N $47^{\circ} 48^{\prime}$ E $24^{\circ} 57^{\prime}, 27.09 .2014$, leg. I.O. Dudka, $K W 70526$; the same place, 20.08.2015, leg. V.P. Heluta, $K W 70530, K W 70531$; Perkalab, N $47^{\circ} 48^{\prime}$ E $24^{\circ} 57^{\prime}, 18,19.08 .2015$, leg. V.P. Heluta, $K W 70527$, $K W 70529$; the same place, near buildings, $\mathrm{N} 47^{\circ} 48^{\prime} \mathrm{E}$ $24^{\circ} 57^{\prime}, 19.08 .2015$, leg. V.P. Heluta, $K W 70528$.

Vyzhnytsia District: Vyzhnytsia National Nature Park, Solonetske environmental parcel, near Chereshenka village, road along brook, $\mathrm{N} 48^{\circ} 11^{\prime} \mathrm{E} 25^{\circ} 15^{\prime}$, 23.08.2015, leg. V.P. Heluta, $K W$ 70532, $K W 70533$; bank of Lekechi river near Lopushna village, $\mathrm{N} 48^{\circ} 06^{\prime}$ E $25^{\circ} 16^{\prime}, 07.09 .2013$, leg. I.O. Dudka, $K W 70515$; bank of Stebnyk river, N $48^{\circ} 08^{\prime}$ E $25^{\circ} 15^{\prime}, 06.09 .2013$, leg. I.O. Dudka, $K W 70514$; young mixt forest near foot of the Kichera Mountain, N 48 $11^{\prime}$ E 2516', 11.09.2013, leg. I.O. Dudka, $K W$ 70519; Sukhyi area, road along Malyi Sukhyi brook, N $48^{\circ} 09^{\prime}$ E $25^{\circ} 15^{\prime}$, 12.09.2013, leg. I.O. Dudka, KW70520.

\section{Ivano-Frankivsk Region}

Kosiv District: outskirts of Kosiv, climb on the Kamianysty Ridge, N 48 $18^{\prime}$ E $25^{\circ} 02^{\prime}, 11.09 .2013$, leg. V.P. Heluta, $K W 70518$; outskirts of Pistyn village,

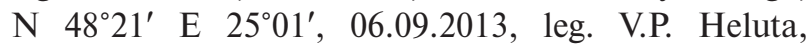
$K W$ 70513; outskirts of Yavoriv village, climb on the Ternoshora mountain, N 48 $14^{\prime}$ E $28^{\circ} 55^{\prime}, 10.09 .2013$, leg. V.P. Heluta, $K W 70516, K W 70517$.

Nadvirna District: Gorgany Nature Reserve, Chernykivske Department, Novobudova, N $48^{\circ} 24^{\prime}$ E $24^{\circ} 22^{\prime}, 09.09 .1914$, leg. V.P. Heluta, $K W$ 70521; near office of the Gorganske Department, N 48 $29^{\prime}$, E $24^{\circ} 16^{\prime}, 26,27,28.08 .2010$, leg. Yu. Ya. Tykhonenko, $K W 70505, K W 70506, K W 70509$; the same place, 11.09.2014, leg. V.P. Heluta, $K W 70522$; right bank of Bystrytsia Nadvirnianska river, near office of the Gorganske Department, 29.08.2010, N 48 29', 


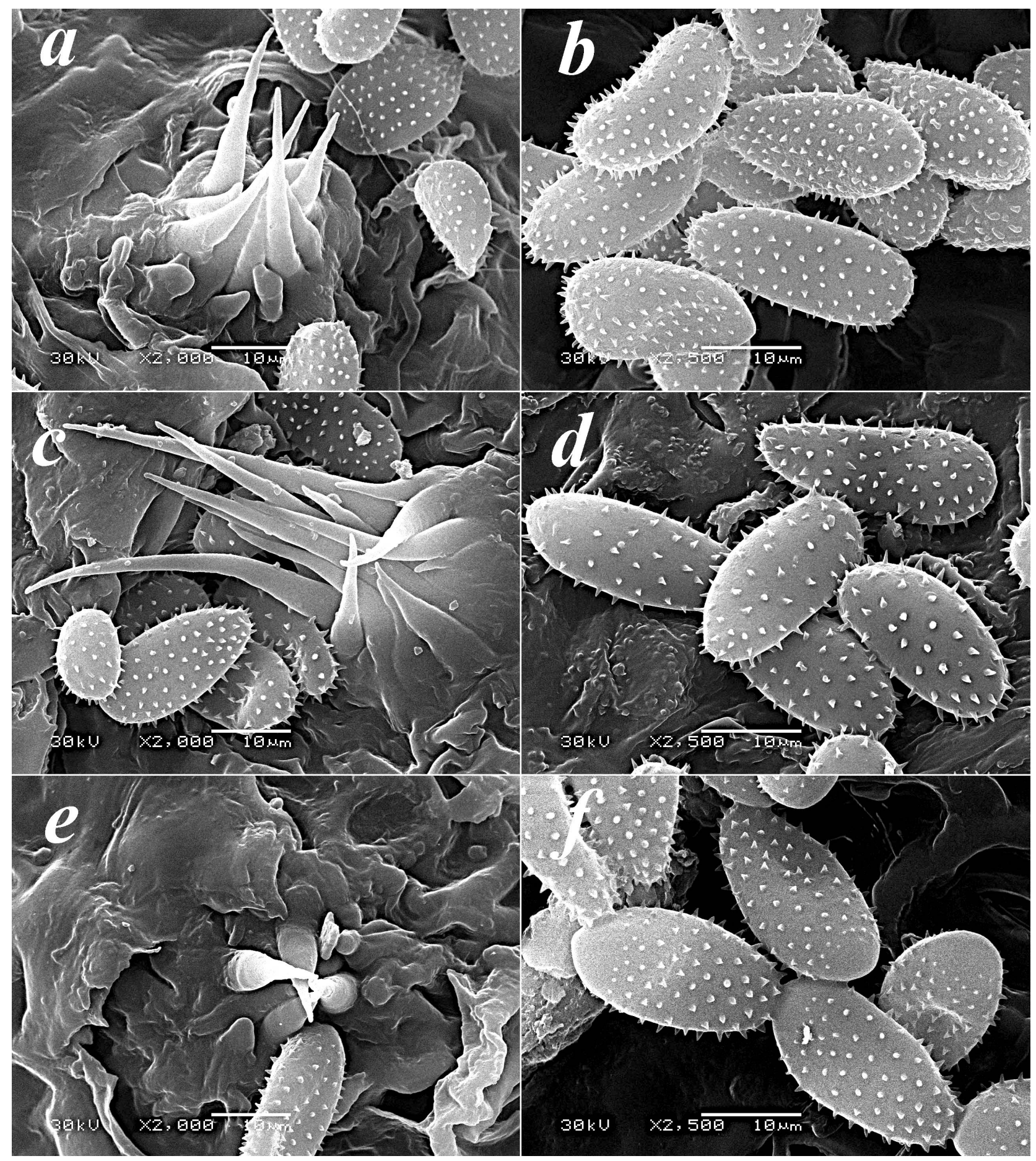

Melampsoridium hiratsukanum on Alnus glutinosa: $a$ - ostiolar cells of uredinium, $b$ - urediniospores. M. hiratsukanum on Alnus $\times$ pubescens: $c$ - ostiolar cells of uredinium, $d$ - urediniospores. M. betulinum on Betula pubescens: $e-$ ostiolar cells of uredinium, $f$ - urediniospores. Scale bars $-10 \mu \mathrm{m}$ 
E $24^{\circ} 16^{\prime}$, leg. Yu.Ya. Tykhonenko, $K W 70510$, $K W$ 70511; forest compartment no.14, 26.08.2010, leg. V.P. Heluta, $K W$ 70507; forest compartment no. 2, N $48^{\circ} 29^{\prime}$, E $24^{\circ} 16^{\prime}, 31.08 .2010$, leg. Yu.Ya. Tykhonenko, $K W 70512$; in the vicinity of the Reserve, Maksymets village, bank of Bystrytsia Nadvirnianska river, $\mathrm{N} 48^{\circ} 30^{\prime}$, E $24^{\circ} 17^{\prime}$, 28.08.2010, leg. V.P. Heluta, $K W 70508$.

Verkhovyna District: Verkhovynskiy National Nature Park, Perkalaba environmental parcel, bank

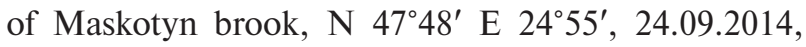
leg. I.O. Dudka, $K W 70525$; forest on the left bank of Perkalab river, N $47^{\circ} 47^{\prime}$ E $24^{\circ} 56^{\prime}$, 21.09.2014, leg. I.O. Dudka, KW70524; bank of Pryluchensky brook, N $47^{\circ} 47^{\prime}$ E $24^{\circ} 55^{\prime}, 22.09 .2014$, leg. I.O. Dudka, $K W 70523$.

Yaremcha town council: Carpathian National Nature Park, Vorokhta environmental parcel, alder and

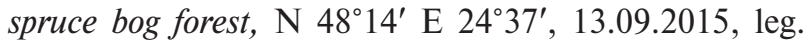
I.O. Dudka, $K W 70534$.

\section{On Alnus glutinosa (L.) P. Gaertn.}

\section{Chernivtsi Region}

Vyzhnytsia District: near Chereshenka village, Vyzhnytsia National Nature Park, Solonetske environmental parcel, $\mathrm{N} 48^{\circ} 11^{\prime} \mathrm{E} 25^{\circ} 15^{\prime}, 23,24.08 .2015$, leg. V.P. Heluta, $K W 70535, K W 70536$.

\section{On Alnus $\times$ pubescens Tausch}

\section{Chernivtsi Region}

Vyzhnytsia District: near Chereshenka village, Vyzhnytsia National Nature Park, Solonetske environmental parcel, along brook, N 48 $11^{\prime}$ E $25^{\circ} 15^{\prime}$, 23.08.2015, leg. V.P. Heluta, $K W 70537$.

\section{REFERENCES}

Bulgakov T.S., Vasilev N.P., Zmitrovich I.V. In: Botanika: istoriya, teoriya, praktika ( $k$ 300-letiyu osnovaniya Botanicheskogo instituta im. V.L. Komarova Rossiyskoy akademii nauk): Trudy mezhdunarodnoy nauchnoy konferentsii, St. Petersburg: SPbGETU LETI, 2014, pp. 31-39. [Булгаков Т.С., Васильев Н.П., Змитрович И.В. Итоги 10-летнего обследования микобиоты породинтродуцентов дендрария научно-опытной станции «Отрадное» Ботанического института им. В. Л. Комарова РАН // Ботаника: история, теория, практика (к 300-летию основания Ботанического института им. В. Л. Комарова Российской академии наук): Труды международной научной конференции. - СПб.: СПбГЭТУ «ЛЭТИ», 2014. - С. 31-39].

Dietrich W. The rust fungi, smut fungi and downy mildews in the Czech part of Krusne hory (Erzgebirge): first supplement, Czech Mycol., 2005, 57(3-4): 257-273.

Gjaerum H.B., Lye K.A., Solheim H. First record of Melampsoridium hiratsukanum on alder in Norway, Plant Pathology, 2004, 53: 530. doi: 10.1111/j.1365-3059.2004.01032.x
Hantula J., Kurkela T., Hendry S., Yamaguchi T. Morphological measurements and ITS sequences show that the new alder rust in Europe is conspecific with Melampsoridium hiratsukanum in eastern Asia, Mycologia, 2009, 101: 622-631. doi: 10.3852/07-164

Hantula J., Nigel Stringer R., Lilja A., Kurkela T. Alder rust, Melampsoridium hiratsukanum Ito, identified from Wales, UK and British Columbia, Canada, Forest Pathol., 2012, 42(4): 348-350. doi: 10.1111/j.1439-0329.2012.00761.x

Hantula, J., Scholler, M. NOBANIS - Invasive Alien Species Fact Sheet -Melampsoridium hiratsukanum, Online Database of the European Network on Invasive Alien Species, available at: http://www.nobanis.org (accessed 21/03/2016).

Henderson D.M., Bennell, A.P. British Rust Fungi: additions and corrections, Notes Roy. Bot. Gard., Edinburgh, 1979, 44(3): 475-501.

Kokeš P. Příspěvek k rozšíření fytopatogenních plísní, rzí a snětí na Slovensku. 1, Mykol. Listy, 2004, 90/91: 24-27.

Kruse J. Phytoparasitische Kleinpilze in den Berchtesgadener und angrenzenden Salzburger Alpen unter besonderer Berücksichtigung des Nationalparks Berchtesgaden, Zeit. Mykol., 2013, 79(1): 99-175.

Kruse J. Diversität der pflanzenpathogenen Kleinpilzeim Ökologisch-Botanischen Garten der Universität Bayreuth, Zeit. Mykol., 2014, 80(1): 169-226.

Kurkela T., Hanso M., Hantula J. Melampsoridium sp. on alder leaves. In: Proceedings of the First IUFRO Rusts of Forest Trees Working Party Conf., Saariselka, Finland, 1998, pp. 131-134.

Kurkela T., Hanso M., Hantula J. Differentiating characteristics between Melampsoridium rusts infecting birch and alder leaves, Mycologia, 1999, 91: 987-992. doi: $10.2307 / 3761629$

Lane C., Berry S.M., Anderson H. Rapid Pest Risk Analysis for Melampsoridium hiratsukanum, Department for Environment, Food \& Rural Affairs, 2013, available at: https://secure.fera.defra.gov.uk/phiw/riskRegister/ downloadExternalPra.cfm?id=3884 (accessed 23 February 2016).

Lilja A., Rytkönen A., Hantula J., Müller M., Parikka P., Kurkela T. Introduced pathogens found on ornamentals, strawberry and trees in Finland over the past 20 years, Agricult. Food Sci., 2011, 20: 74-85. doi: 10.2137/145960611795163051

Markovskaja S. Melampsoridium hiratsukanum - invasive rust species in Lithuania, and its co-occurrence with eriophyid mite, Acta Mycol., 2013, 48(2): 197-205. doi: 10.5586/am.2013.021

McKenzie E.H.C., Padamsee M., Dick M. First report of rust on Alnus in New Zealand is Melampsoridium betulinum, not M. hiratsukanum. Plant Pathology \& Quarantine, 2013, 3(2): 59-65. doi: 10.5943/ppq/3/2/1

Meier F., Engesser R., Forster B., Odermatt O. ForstschutzÜberblick 2002, Birmersdorf, Switzerland: Eidgenössische Forschungsanstalt WSL, 2003, 24 S.

Moricca S., Maresi G. Melampsoridium hiratsukanum reported for the first time on grey alder in Italy, New Disease Reports, 2010,21: 17.doi: 10.5197/j.2044-0588.2010.021.017 
Mułenko W., Bacigálová K., Kozłowska M. Parasitic microfungi of the Tatra Mountains 4. Melampsoridium hiratsukanum (Urediniomycetes), Pol. Bot. Stud., 2006, 22: 399-405.

Müller J. Rost-, Brand- und Falsche Mehltaupilze neu für Mähren und tschechisch Schlesien, Czech Mycol., 2003, 55(3/4): 277-290.

Negrean G., Anastasiu P. Invasive and potentially invasive parasite neomycetes from Romania. In: Plant, fungal and habitat diversity investigation and conservation. Proceedings of IV BBC, Sofia, 2006, pp. 514-519.

Piątek M., Ronikier M., Miśkiewicz A. New records and new host for Melampsoridium hiratsukanum (Fungi, Uredinales) in Poland, Fragm. Flor. Geobot. Polonica, 2001, 8: $245-249$.

Põldmaa K. Explosion of Melampsoridium sp. on Alnus incana, Folia Cryptog. Estonica, 1997, 31: 48-50.

Riegler-Hager H., Scheuer C., Zwetko P. Der Erlen-Rost Melampsoridium hiratsukanum in Österreich, Wulfenia, 2003, 10: 135-143.

Roll-Hansen F., Roll-Hansen H. Melampsoridium on Alnus in Europe. M. alni conspecific with M. betulinum, Europ. J. Forest Pathology, 1981, 11: 77-87.

Scholler M. Obligate phytoparasitic neomycetes in Germany: Diversity, distribution, introduction patterns, and consequences. In: U. Doyle (ed.). Alien organisms in Germany. Documentation of a Conference on March 6-7, 1998. «Legal regulations concerning Alien Organisms in Comparison to genetically modified Organisms», Berlin: Federal Environ. Agency (Umweltbundesamt), 1999, pp. 64-75.

Scholler M., Besl, H., Bresinsky A. Additions to the rust flora of Bavaria, Zeit. Mykol., 2010, 76: 171-176.

Sert H., Sümbül H. First report of Melampsoridium hiratsukanum infecting alder (Alnus orientalis var. orientalis) in Turkey, Plant Pathology, 2005, 54: 241. doi: 10.1111/j.1365-3059.2005.01131.x

Stringer R.N. New rust for Pembrokeshire, Pembrokeshire Fungus Recorder, 2010, 1: 4-5.

Szabo I. First report of Melampsoridium hiratsukanum on common alder in Hungary, Plant Pathology, 2002, 51: 804. doi: 10.1046/j.1365-3059.2002.00776.x

Tykhonenko Yu.Ya. First record of the rust fungus Melampsoridium hiratsukanum S. Ito in Ukraine, Ukr. Bot. J., 2011, 68(1): 129-132.

Tykhonenko Yu.Ya., Heluta V.P. Rust fungi of Hutsulshchyna National Nature Park, Ukr. Bot. J., 2014, 71(4): 489-495. doi: 10.15407/ukrbotj71.04.489

Vanderweyen A. Melampsoridium betulinum (Fr.) Kleb. sur aulne glutineux en Belgique, Revue du Cercle de Mycologie de Bruxelles, 2010, 10: 15-22.

Wilson M., Henderson D.M. British Rust Fungi, Cambridge: Cambridge Univ. Press, 1966, 384 pp.

Wołczanska A. Melampsoridium hiratsukanum (Uredinales), a new species for Poland, Acta Mycol., 1999, 34(2): 345347. doi: 10.5586/am.1999.023

Recommended for publication by Submitted 16.03.2016 V.P. Hayova
Тихоненко Ю.Я., Гелюта В.П., Дудка І.О. Нові знахідки інвазійного гриба Melampsoridium hiratsukanum (Pucciniales) в Україні. - Укр. ботан. журн. - 2016. 73(4): 385-389.

Інститут ботаніки ім. М.Г. Холодного НАН України вул. Терещенківська, 2, м. Київ, 01004, Україна

Повідомляється про знахідки на території Національного природного парку «Вижницький» (Чернівецька обл., Україна) інвазійного іржастого гриба Melampsoridium hiratsukanum на нових для України живильних рослинах Alnus glutinosa i Alnus $\times$ pubescens, природному гібриді A. incana і A. glutinosa. Нині в Европі M. hiratsukanum відомий з Австрії, Великобританії, Данії, Естонії, Італії, Латвії, Литви, Німеччини, Норвегії, Польщі, Росії, Румунії, Словаччини, Туреччини, Угорщини, України, Фінляндії, Чеської республіки, Швейцарії та Швеції. На сьогодні поширення $M$. hiratsukanum в Україні обмежується регіоном Українських Карпат, хоча в майбутньому, з огляду на освоєння цим грибом $A$. glutinosa, не можна виключати його розповсюдження і на рівнинну частину країни. Наведено список усіх локалітетів, у тому числі декілька нових, у яких в Україні був відмічений M. hiratsukanum. Робота ілюстрована мікрофотографіями, отриманими за допомогою сканувального електронного мікроскопа.

Ключові слова: іржасті гриби, Alnus glutinosa, Alnus $\times$ pubescens, Карпати, поширення, морфологія

Тихоненко Ю.Я., Гелюта В.П., Дудка И.А. Новые находки в Украине инвазионного гриба Melampsoridium hiratsukanum (Pucciniales). - Укр. ботан. журн. - 2016. 73(4): 385-389.

Институт ботаники имени Н.Г. Холодного НАН Украины

ул. Терещенковская, 2, г. Киев, 01004, Украина

Сообщается о нахождении на территории Национального природного парка «Выжницкий» (Черновицкая обл., Украина) инвазионного ржавчинного гриба Melampsoridium hiratsukanum на новых для Украины питающих растениях - Alnus glutinosa и Alnus $\times$ pubescens, природном гибриде $A$. incana и A. glutinosa. На сегодня в Европе M. hiratsukanum известен из Австрии, Великобритании, Венгрии, Германии, Дании, Италии, Латвии, Литвы, Норвегии, Польши, России, Румынии, Словакии, Турции, Украины, Финляндии, Чешской республики, Швейцарии, Швеции и Эстонии. В настоящее время распространение M. hiratsukanum в Украине ограничивается регионом Украинских Карпат, хотя в будущем, учитывая освоение этим грибом A. glutinosa, нельзя исключить возможность его проникновения и на равнинную часть страны. Приведен список всех локалитетов, в том числе несколько новых, в которых в Украине был отмечен M. hiratsukanum. Работа иллюстрирована микрофотографиями, полученными с помощью сканирующего электронного микроскопа.

Ключевые слова: ржавчинные грибы, Alnus glutinosa, Alnus $\times$ pubescens, Карпаты, распространение, морфология 